\title{
KARAKTERISTIK PRODUK BUBUK SARI JAGUNG MANIS INSTAN HASIL PENGERINGAN METODE SPOUTED-VORTEX-BED
}

\author{
[Characteristics of Instant Sweet Corn Extract Powders Produced by Spouted-Vortex-Bed Drying Method]
}

\author{
Iwan Taruna*, Neti Surami dan Sutarsi \\ Jurusan Teknik Pertanian, Fakultas Teknologi Pertanian, Universitas Jember, Jember
}

Diterima 04 November 2013 / Disetujui 27 Januari 2014

\begin{abstract}
The characteristics of instant sweet corn extract powders produced by a spouted-vortex-bed (SVB) drying method was investigated as affected by the drying conditions. The sweet corn extract was prepared from shelled corn kernels of Bisi Sweet variety through washing, blanching, grinding, extracting and separating the soluble extract from the insoluble residue using a centrifugal filter. The extract was then dried at various drying conditions including inlet temperature $\left(100-120^{\circ} \mathrm{C}\right)$, airflow rates $\left(245-323 \mathrm{~m}^{3} / \mathrm{h}\right)$, feed rates $(0.6-1.5 \mathrm{~kg} / \mathrm{h})$ and mass of Teflon pellets $(0.7-1.3 \mathrm{~kg})$. The dried products were sieved to obtain $\leq 60$ mesh powders and analyzed for its moisture content, colour attributes, density, solubility index, and water absorption capacity. The results showed that an increase in inlet temperatures and mass of Teflon pellets tended to decrease the moisture content of the powders. In most cases, the inlet temperatures influenced the $L, a, b$ values of the sweet corn extract powders colour. An increase in the inlet temperatures decreased the $L$ and $b$ values, but increased significantly the a value of the sweet corn extract powders. The effect of feed rates on the density of instant powders was identified only for drying temperatures between 100 and $120^{\circ} \mathrm{C}$. Increasing both airflow rates and inlet temperature at the mass of Teflon pellets of $1.3 \mathrm{~kg}$ decreased the solubility index of the sweet corn extract powders. Water absorption capacity of the sweet corn extract powders was influenced mainly by the airflow rate, feed rate and mass of inert particles.
\end{abstract}

Keywords: drying effect, instant powder, spouted-vortex-bed, sweet corn extract

\section{ABSTRAK}

Evaluasi karakteristik bubuk sari jagung manis hasil pengeringan metode spouted-vortex-bed telah ditentukan berdasarkan pengaruh kondisi pengeringan. Sari jagung manis dibuat dari pipilan jagung varietas Bisi Sweet yang diproses melalui tahapan pencucian, blansing, penggilingan, ekstraksi dan pemisahan antara bagian terlarut dan padatan. Bagian terlarut sari jagung manis selanjutnya dikeringkan pada beragam kombinasi variabel pengeringan yaitu suhu inlet $\left(100-120^{\circ} \mathrm{C}\right)$, laju udara pengering $(245-323 \mathrm{~m} / \mathrm{h})$, laju pengumpanan bahan $(0.6-1.5 \mathrm{~kg} / \mathrm{h})$ dan massa partikel inert berupa butiran Teflon $(0.7-1.3 \mathrm{~kg})$. Produk hasil pengeringan sari jagung manis kemudian diayak untuk memperoleh butiran bubuk berukuran $\leq 60$ mesh sebelum dilakukan penentuan parameter mutu bubuk sari jagung manis yang meliputi kadar air bahan, atribut warna, densitas $\left(\rho_{p}\right)$, indeks kelarutan $(\mathrm{SI})$ dan kapasitas absorbsi air $\left(\mathrm{W}_{\mathrm{a}}\right)$. Hasil percobaan menunjukkan bahwa peningkatan suhu inlet pengeringan dan jumlah penggunaan butiran Teflon cenderung menurunkan kadar air produk akhir bubuk sari jagung manis. Parameter warna $L$, a dan $b$ bubuk sari jagung manis lebih dominan dipengaruhi oleh perubahan suhu pengeringan. Peningkatan suhu pengeringan menyebabkan penurunan nilai $L$ dan b, namun menunjukkan korelasi positif yang nyata dengan nilai a. Pengaruh laju pengumpanan bahan terhadap densitas partikel bubuk sari jagung manis instan tampak nyata pada suhu pengeringan antara 100 dan $120^{\circ} \mathrm{C}$. Peningkatan laju udara pengering dan suhu pengeringan pada saat $\mathrm{m}$ $=1.3 \mathrm{~kg}$ menghasilkan penurunan SI bubuk sari jagung manis instan, sedangkan nilai $\mathrm{W}_{\mathrm{a}}$ bubuk sari jagung manis yang dihasilkan lebih banyak dipengaruhi oleh laju udara pengering, laju pengumpanan bahan dan massa partikel inert.

Kata kunci: bubuk instan, efek pengeringan, sari jagung manis, spouted-vortex-bed

\section{PENDAHULUAN}

Jagung manis (Zea mays var. saccharata) akhir-akhir ini banyak diminati masyarakat karena kelezatan dan manfaat gizinya bagi pertumbuhan dan produktivitas fisik manusia. Perbedaan pokok bulir jagung manis dengan jagung biasa terletak pada struktur biji yang lebih lunak dan kadar gula yang lebih tinggi. Pada setiap $100 \mathrm{~g}$ biji jagung manis terkandung $22.8 \mathrm{~g}$ karbohidrat, $3.5 \mathrm{~g}$ protein dan $1.0 \mathrm{~g}$ lemak (Iskandar,

*Penulis Korespondensi:

E-mail: taruna@unej.ac.id;Telepon: +628123483776
2003). Ghorpade et al. (1998) menyatakan bahwa pemanfaatan jagung manis seringkali dikonsumsi dalam bentuk segar atau diolah untuk dikalengkan maupun dibekukan. Berdasarkan tinjauan aspek eating quality, mutu jagung manis segar maupun olahan sangat ditentukan oleh keunikan kombinasi dari rasa, tekstur dan aromanya (Lertrat dan Pulam, 2007).

Penggunaan jagung manis di Indonesia pada umumnya masih dalam bentuk bebijian segar yakni digunakan sebagai bahan tambahan makanan atau diolah menjadi produk jagung bakar dan rebus. Metode pemanfaatan jagung manis tersebut akan membatasi variasi olahannya dan menghasilkan nilai tambah yang rendah (Welirang, 2002). Dalam rangka mengatasi hal tersebut, beragam upaya telah dilakukan untuk me- 
ngembangkan produk pangan baru berbasis jagung maupun jagung manis antara lain berupa susu asam atau yogurt (Supavititpatana et al. 2009; Liu-juan et al. 2011; Setiawati dan Puspitojati, 2011; Sangsila et al. 2012; Nofrianti et al. 2013), susu nabati dari jagung manis (Wen-ming et al. 2004; Xing-wu, 2006), susu nabati dari fortifikasi jagung manis dan kedelai (Srianta et al. 2010; Trisnawati et al. 2013; Setiawati dan Puspitojati, 2011) dan susu nabati hasil campuran jagung manis dan kacang hijau (Setyani et al. 2009). Hasil pengembangan beragam produk tersebut ternyata mulai menarik perhatian konsumen berbagai negara termasuk Indonesia dan berpotensi menjanjikan keuntungan ekonomi. Bertolak dari kondisi tersebut maka riset ini bermaksud untuk mengembangkan produk bubuk sari jagung manis instan yang berfungsi baik sebagai bahan minuman maupun bahan baku pengolahan pangan. Keuntungan yang diperoleh dari memproduksi pangan berbasis tepung/bubuk yakni mempermudah fortifikasi dengan produk lain, meningkatkan daya simpan, dan menghemat biaya pengemasan dan transportasi (Manurung, 2011).

Keberhasilan pengolahan bahan pangan cair menjadi produk bubuk instan biasanya sangat ditentukan oleh operasi pengeringan menggunakan drum atau spray dryer. Sutardi et al. (2010) telah menggunakan spray dryer untuk memproduksi bubuk sari jagung manis. Sifat fisik dan kimia produk yang dihasilkan dipengaruhi oleh jumlah dan jenis bahan pengisi yang berupa dekstrin dan gum arab Meskipun demikian, penggunaan drum atau spray dryer diyakini tidak ekonomis bagi kalangan industri skala kecil menengah di Indonesia karena menyerap biaya investasi dan operasional yang cukup mahal. Salah satu opsi teknik pengeringan yang berpotensi digunakan untuk memproduksi bubuk instan adalah metode pengeringan tipe spouted-vortex-bed (SVB) yakni proses pengeringan menggunakan media partikel inert yang terfluidisasi di dalam unit pengontak gas-partikel atau ruang pengering. Berdasarkan kajian Kudra dan Mujumdar (2009), sistem pengeringan menggunakan media partikel inert terfluidisasi mempunyai kinerja yang setara dengan spray dryer maupun drum dryer, namun memiliki efisiensi termal yang relatif lebih tinggi dan biaya instalasi yang terjangkau. Meskipun demikian, eksperimen aplikasi pengeringan SVB untuk proses produksi bubuk sari jagung manis instan hingga kini masih belum pernah dilakukan di Indonesia. Hal ini dibuktikan dengan terbatasnya informasi tersebut di publikasi ilmiah nasional maupun internasional. Karena itu, tujuan penelitian ini adalah untuk melakukan investigasi pengaruh variabel kondisi pengeringan SVB yang terdiri dari suhu inlet pengeringan, laju udara pengering, laju pengumpanan bahan dan massa partikel inert terhadap karakteristik mutu bubuk sari jagung manis instan yang dihasilkan.

\section{BAHAN DAN METODE}

\section{Bahan}

Bahan untuk percobaan pengeringan adalah larutan sari jagung manis yang dibuat berdasarkan metode dalam Prabhavat et al. (1999). Bulir jagung manis varietas Bisi sweet dicuci, diblansing dengan uap air panas pada suhu $100^{\circ} \mathrm{C}$ selama \pm 15 menit, lalu ditiriskan. Hasil blansing bulir jagung manis selanjutnya digiling bersama air dengan rasio berat bulir:air sebesar 1:2 untuk menghasilkan bubur jagung manis. Larutan sari jagung manis diperoleh dengan cara memisahkan bagian terlarut (soluble) dari bubur jagung manis dengan menggunakan unit penyaring sentrifugal. Larutan sari jagung manis yang diperoleh memiliki kadar air berkisar $91-93 \%$ (bb) dan dijadikan bahan percobaan pengeringan.

\section{Pengeringan sari jagung manis}

Eksperimen pengeringan sari jagung manis dilakukan di Laboratorium Enjiniring Hasil Pertanian Fakultas Teknologi Pertanian Universitas Jember, menggunakan unit pengering SVB yang ilustrasinya tercantum pada Gambar 1. Unit pengering SVB merupakan hasil modifikasi unit pengering sejenis yang telah dikembangkan Taruna et al. (2005). Total percobaan pengeringan berjumlah delapan puluh satu kali yang terdiri dari kombinasi variabel kondisi pengeringan seperti terdapat pada Tabel 1.

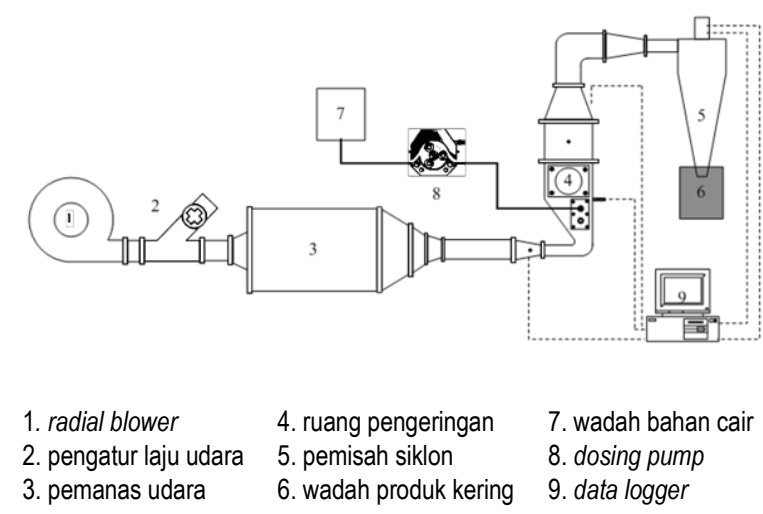

Gambar 1. Unit pengering bahan cair tipe spouted-vortex-bed (SVB)

Tabel 1. Kondisi percobaan pengeringan sari jagung manis dengan metode SVB

\begin{tabular}{ccc}
\hline Variabel Eksperimen & Kondisi & Satuan \\
\hline Suhu inlet pengering $(\mathrm{T})$ & $100,110,120$ & ${ }^{\circ} \mathrm{C}$ \\
Laju udara pengering $(\mathrm{Q})$ & $245,285,323$ & $\mathrm{~m} 3 / \mathrm{jam}$ \\
Laju pengumpanan bahan $(\mathrm{F})$ & $0.6,1.1,1.5$ & $\mathrm{~kg} / \mathrm{jam}$ \\
Massa partikel inert $(\mathrm{m})$ & $0.7,1.0,1.3$ & $\mathrm{~kg}$ \\
\hline
\end{tabular}

Beberapa data penting yang juga dicatat selama percobaan pengeringan meliputi suhu lingkungan (bola basah dan kering), suhu masuk dan keluar ruang pengering, laju pengumpanan bahan dan waktu pengeringan. Proses pengeringan larutan sari jagung manis berlangsung di bagian ruang pengeringan unit SVB yang berisi partikel inert dari bahan Teflon berbentuk kubus kecil berukuran $\pm 5 \mathrm{~mm}$ setiap sisinya. Saat berlangsungnya proses pengeringan, partikel inert tersebut terfluidisasi secara kontinyu karena hembusan udara panas berkecepatan tinggi yang disuplai oleh blower radial berdaya $0.75 \mathrm{~kW}$. Energi panas udara pengering tersebut dihasilkan dari pemanasan udara oleh 6 elemen listrik yang seluruhnya dirangkai dalam tiga sirkuit paralel dengan total daya $9 \mathrm{~kW}$. Bahan cair sari jagung manis dialirkan ke ruang pengering menggunakan dosing pump tipe Chem-Tech 100/150. Produk sari jagung 
manis kering diperoleh setelah dipisahkan dari udara pengering oleh pemisah siklon (cyclone separator) dan ditampung dalam wadah penampung dari bahan acrylic. Bubuk sari jagung manis kemudian dikemas dalam plastik kedap udara dan disimpan pada suhu $\pm 4^{\circ} \mathrm{C}$ kurang dari 4 hari sebelum dilakukan evaluasi mutu.

\section{Analisa karakteristik bubuk sari jagung manis}

Mutu produk bubuk sari jagung manis instan hasil pengeringan SVB dievaluasi berdasarkan parameter kadar air, warna, densitas $\left(\rho_{\mathrm{p}}\right)$, indeks kelarutan (SI) dan kapasitas absorpsi air $\left(\mathrm{W}_{\mathrm{a}}\right)$. Analisa mutu sampel hasil percobaan dilakukan terbatas hanya pada produk bubuk sari jagung manis yang berhasil dikeringkan oleh kondisi pengeringan SVB selama percobaan. Sebelum dilakukan analisa mutu, ukuran partikel sampel diseragamkan menjadi $\leq 60$-mesh melalui proses pengecilan ukuran dan pengayakan.

Kadar air bubuk sari jagung manis ditentukan dengan cara mengeringkan rangkap tiga sampel masing-masing $\pm 5 \mathrm{~g}$ dalam oven Memmert WNB14 pada suhu sesuai AOAC (1999) yaitu $105^{\circ} \mathrm{C}$ selama 5 jam atau lebih hingga beratnya konstan dengan ketelitian $\pm 0.001 \mathrm{~g}$. Pengukuran warna bubuk sari jagung manis instan bertujuan mengkuantifikasi sifat warna produk dalam bentuk parameter $L$, $a$ dan $b$. Parameter $L$ merepresentasikan sifat terang dan gelap warna produk dengan rentang nilai L mulai 0 berarti "hitam gelap" hingga 100 berarti warna "putih". Parameter a menunjukkan interval warna antara hijau (100) dan merah $(+100)$, sedangkan parameter b menunjukkan rentang warna antara biru $(-100)$ dan warna kuning $(+100)$. Pengukuran nilai $L$, a dan b dilakukan sebanyak enam kali ulangan pada setiap sampel produk menggunakan color reader Minolta (CR-10). Densitas partikel $\left(\rho_{p}\right)$ bubuk sari jagung manis ditentukan berdasarkan metode liquid displacement yang telah dijabarkan dalam Mohsenin (1980). Indeks kelarutan (SI) bubuk sari jagung manis instan ditentukan berdasarkan metode dalam Lees (1971), yaitu sekitar $13 \mathrm{~g}$ sampel dicampur dengan 100 $\mathrm{mL}$ air suling selama 3 menit dan selanjutnya dibiarkan selama 15 menit sebelum disentrifugasi pada kecepatan 1000 RPM selama 5 menit. Jumlah total zat padat didalam supernatant ditentukan dengan cara pengeringan di oven pada suhu $100^{\circ} \mathrm{C}$ hingga mencapai berat konstan, yang dilanjutkan dengan pendinginan dalam desikator hingga mencapai suhu ruang sebelum ditimbang. Nilai SI dihitung sebagai rasio antara zat padat di supernatant dengan zat padat yang ada di larutan awal sari jagung manis. Penentuan sifat kapasitas absorpsi air $\left(\mathrm{W}_{\mathrm{a}}\right)$ bubuk sari jagung manis instan dilakukan menggunakan modifikasi metode dalam Traina dan Breene (1994). Sampel seberat $1.05-1.36 \mathrm{~g}$ dicampur dengan $10 \mathrm{~mL}$ air suling di dalam test tube, dikocok selama 1 menit dan kemudian didiamkan selama 30 menit pada suhu ruang. Selanjutnya test tube disentrifugasi dengan kecepatan 2000 RPM selama 25 menit. Jumlah air yang tertahan pada sampel setelah penirisan test tube disebut kapasitas absorpsi air.

\section{Metode analisa data}

Data hasil percobaan pengeringan ini diolah menggunakan program SPSS 14.0 (versi evaluasi). Analisa statistik yang dilakukan meliputi penentuan koifisien korelasi "pearson product-moment" antara variabel kondisi pengeringan metode SVB dengan parameter mutu produk bubuk sari jagung manis instan. Analisis grafik juga dilakukan untuk menganalisa pengaruh dari perbedaan variabel kondisi pengeringan terhadap karakterisitik mutu bubuk sari jagung manis instan. Penyajian data pada grafik yang disusun adalah dalam bentuk rata-rata \pm standard deviasi (SD).

\section{HASIL DAN PEMBAHASAN}

\section{Karakteristik produk bubuk sari jagung manis instan}

Nilai koefisien korelasi $(r)$ antara kondisi pengeringan SVB yang meliputi suhu pengeringan $(\mathrm{T})$, laju pengumpanan bahan $(F)$, kecepatan udara pengering $(\mathrm{Q})$ dan massa partikel inert $(\mathrm{m})$ dengan parameter mutu produk bubuk sari jagung manis instan dipresentasikan pada Tabel 2. Penentuan koefisien korelasi tersebut menghasilkan informasi penting berupa hasil analisa statistik tentang pengaruh variabel kondisi pengeringan terhadap karakteristik mutu produk bubuk sari jagung manis instan seperti diuraikan dan didiskusikan berikut ini.

Tabel 2. Koefisien korelasi (r) antara variabel kondisi pengeringan dengan parameter mutu bubuk sari jagung manis instan

\begin{tabular}{ccccc}
\hline \multirow{2}{*}{ Mutu } & \multicolumn{4}{c}{ Variabel Kondisi Pengeringan } \\
\cline { 2 - 5 } & $\begin{array}{c}\mathrm{T} \\
\left({ }^{\circ} \mathrm{C}\right)\end{array}$ & $\begin{array}{c}\mathrm{F} \\
(\mathrm{kg} / \mathrm{h})\end{array}$ & $\begin{array}{c}\mathrm{Q} \\
\left(\mathrm{m}^{3} / \mathrm{jam}\right)\end{array}$ & $\begin{array}{c}\mathrm{m} \\
(\mathrm{kg})\end{array}$ \\
\hline $\mathrm{KA}$ & -0.143 & 0.135 & -0.064 & $-0.366^{*}$ \\
$\mathrm{~L}$ & $-0.577^{*}$ & $0.202^{*}$ & $-0.161^{*}$ & $0.159^{*}$ \\
$\mathrm{a}$ & $0.480^{*}$ & -0.020 & 0.084 & $-0.281^{*}$ \\
$\mathrm{~b}$ & $-0.415^{*}$ & 0.056 & $-0.161^{*}$ & $0.667^{*}$ \\
$\rho_{\mathrm{p}}$ & -0.088 & $0.412^{*}$ & 0.010 & $0.333^{*}$ \\
$\mathrm{SI}$ & $-0.430^{*}$ & -0.174 & -0.245 & $\mathrm{n} / \mathrm{a}$ \\
$\mathrm{W}_{\mathrm{a}}$ & 0.002 & $0.411^{*}$ & $-0.479^{*}$ & $0.403^{*}$ \\
\hline * Signifikan pada $p \leq 0.01$ & & &
\end{tabular}

\section{Kadar air produk}

Hasil percobaan pengeringan larutan sari jagung manis menunjukkan bahwa unit pengering SVB mampu menghasilkan produk bubuk instan dengan kadar air (KA) berkisar 3-11\% (bb) dari bahan baku sari jagung manis dengan KA sekitar 91-93\% (bb). Proses pengeringan ini ditargetkan untuk menghasilkan KA akhir produk bubuk sari jagung manis kurang dari $6 \%$ (bb). Hasil observasi menunjukkan bahwa sekitar $65 \%$ dari total sampel sari jagung manis yang dikeringkan dengan kondisi pengeringan SVB pada percobaan ini memiliki $\mathrm{KA} \leq 6 \%(\mathrm{bb})$.

KA bubuk sari jagung manis hasil percobaan pengeringan SVB menunjukkan korelasi positif dengan laju pengumpanan bahan $(F)$ dan korelasi negatif dengan suhu pengeringan $(T)$, massa biji Teflon $(\mathrm{m})$ dan kecepatan udara pengeringan $(\mathrm{Q})$. Tabel 2 menunjukkan bahwa peningkatan nilai variabel $(\mathrm{m})$ dapat secara nyata menurunkan KA akhir produk bubuk sari jagung manis dengan nilai koefisien korelasi ( $r$ ) sebesar -0.366 . Meskipun tidak nyata, peningkatan suhu pengeringan $(T)$ juga menunjukkan korelasi yang berlawanan dengan KA akhir bubuk instan $(r=-0.143)$. Peningkatan suhu pengeringan dan jumlah butiran Teflon dapat meningkatkan kapasitas energi pengeringan dan luas bidang kontak pindah panas konduksi antara partikel inert dengan sari jagung manis cair, sehingga kemampuan menguapkan air dari bahan sari jagung manis oleh 
unit pengering dapat meningkat dan menghasilkan KA produk yang lebih kecil. Gambar 2 menunjukkan bahwa sampel bubuk sari jagung manis dengan KA kurang dari $6 \%$ (bb) ternyata mayoritas dihasilkan oleh proses pengeringan yang dijalankan pada suhu pengeringan $110-120^{\circ} \mathrm{C}$ dan jumlah butiran Teflon yang antara 1.0 dan $1.3 \mathrm{~kg}$. Kadar air bubuk sari jagung manis instan yang rendah lebih menjamin waktu simpan yang lebih panjang dibandingkan dengan sampel berkadar air tinggi.

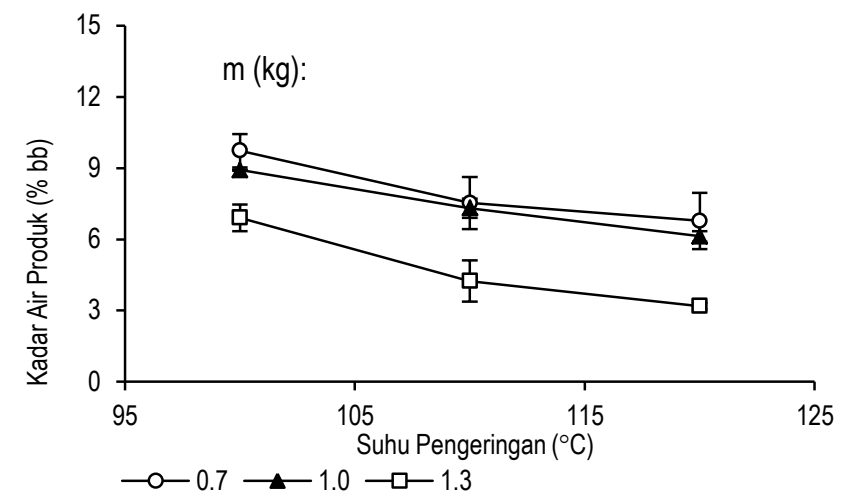

Gambar 2. Hubungan suhu pengeringan dengan kadar air produk pada saat $F=1.0 \mathrm{~kg} / \mathrm{jam}$ dan $Q=323 \mathrm{~m}^{3} / \mathrm{jam}$

\section{Warna produk}

Penampilan warna bubuk sari jagung manis instan adalah parameter penting yang menentukan respon penerimaan konsumen terhadap produk tersebut. Pengaruh kondisi proses pengeringan SVB pada kualitas warna produk akhir dapat diukur menggunakan nilai $L$, a dan $b$ yang ditentukan berdasarkan sistem Hunter $L a b$. Beberapa atribut warna yang digunakan dalam percobaan ini mengindikasikan mutu warna bubuk sari jagung manis secara menyeluruh yang terdiri dari lightness (kecerahan) dan yellowness (kekuningan).

Tingkat kecerahan (lightness) warna sampel bubuk sari jagung manis instan ditunjukkan dengan nilai $L$ yang berkisar 48.7-66.9 tergantung pada kondisi pengeringan. Variasi nilai $L$ sampel tersebut sangat dipengaruhi oleh variabel-variabel kondisi pengeringan yang meliputi $\mathrm{T}, \mathrm{F}, \mathrm{Q}$ dan $\mathrm{m}$. Tabel 2 menunjukkan bahwa peningkatan suhu $(r=-0.577)$ dan laju kecepatan udara $(r=-0.161)$ pengeringan merupakan faktor yang dapat mereduksi tingkat kecerahan warna sampel bubuk instan secara signifikan. Dalam percobaan ini, suhu pengeringan menjadi faktor paling penting yang menentukan tingkat kecerahan warna sampel bubuk instan dibandingkan variabel kondisi pengeringan lainnya. Hal ini dapat disebabkan oleh semakin tingginya suplai energi panas dan telah melebih kebutuhan untuk penguapan air sampel sari jagung manis, sehingga memfasilitasi terjadinya browning pada bahan yang dikeringkan dan akan mengurangi sifat kecerahan produk akhirnya. Namun demikian, nilai L sampel bubuk sari jagung manis instan memiliki korelasi positif yang nyata dengan laju pengumpanan bahan $(r=0.202)$ dan jumlah partikel inert $(r=$ 0.159). Gambar 3 membuktikan bahwa kenaikan laju pengumpanan bahan $(F)$ akan meningkatkan nilai lightness $(\mathrm{L})$ warna sampel bubuk sari jagung manis.

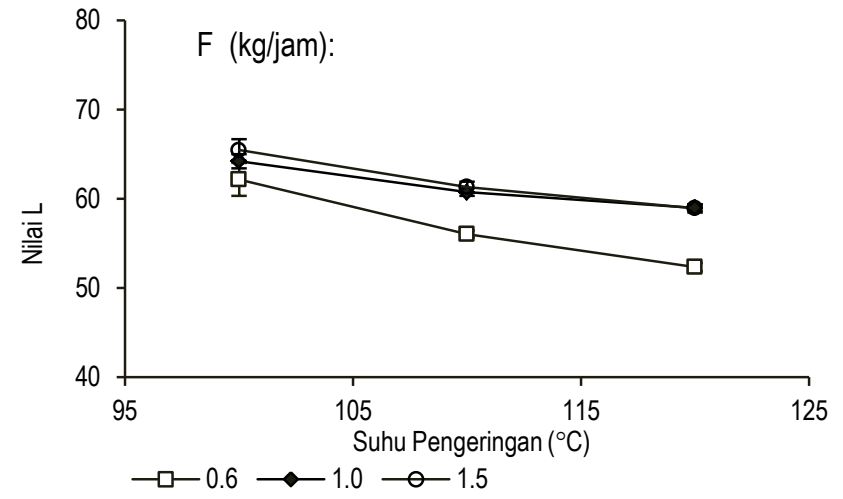

Gambar 3. Hubungan suhu pengeringan dengan nilai $L$ warna bubuk sari jagung manis pada saat $m=0.7-1.3 \mathrm{~kg}$ dan $Q=323$ $\mathrm{m}^{3} / \mathrm{jam}$

Nilai parameter warna "a" produk bubuk sari jagung manis hasil percobaan pengeringan SVB menunjukkan skala berkisar mulai -5.9 hingga 11.9. Nilai a sampel bubuk sari jagung manis sangat dipengaruhi secara nyata oleh suhu pengeringan ( $r=$ $0.480)$ dan massa butiran Teflon ( $r=-0.281)$. Tabel 2 menggambarkan bahwa peningkatan suhu pengeringan $(\mathrm{T})$ dan massa Teflon $(\mathrm{m})$ ternyata memberikan pengaruh yang berlawanan terhadap karakteristik nilai a sampel bubuk instan yaitu mengakibatkan peningkatan nilai a untuk variabel $T$ dan penurunan nilai a untuk variabel $\mathrm{m}$. Gambar 4 menunjukkan bahwa pengaruh kedua variabel pengeringan tersebut yaitu $T$ dan $\mathrm{m}$ terhadap nilai a sampel bubuk instan tampak lebih nyata pada saat suhu pengeringan lebih besar dari $100^{\circ} \mathrm{C}$. Hal ini memberikan indikasi bahwa peningkatan suhu pengeringan dan penurunan jumlah butiran Teflon dalam ruang pengering SVB dapat menghasilkan bubuk sari jagung manis dengan atribut warna kemerahan (redness) yang cenderung lebih tinggi.

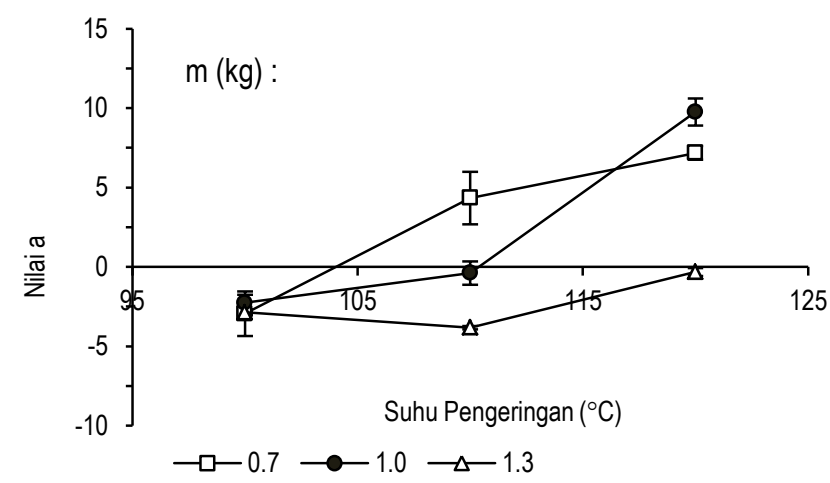

Gambar 4. Hubungan suhu pengeringan $(T)$ dengan nilai a warna bubuk sari jagung manis pada saat $F=1.0 \mathrm{~kg} / \mathrm{jam}$ dan $Q=$ $323 \mathrm{~m}^{3} / \mathrm{jam}$

Kesan sifat yellowness (warna kekuningan) sampel bubuk sari jagung manis instan diukur dengan nilai $b$ dan menunjukkan rentang nilai dari 21.6 sampai 49.1 yang tergantung pada kondisi pengeringan. Secara berurutan, faktor terpenting penentu variasi nilai $b$ produk tersebut adalah massa Teflon $(\mathrm{m})$, suhu pengeringan $(T)$, laju udara pengering $(Q)$ dan laju pengumpanan bahan $(F)$. Tabel 2 menunjukkan bahwa nilai $b$ pada sampel bubuk sari jagung manis instan meningkat secara nyata pada saat pengering SVB dioperasikan pada suhu (T) 
dan laju udara (Q) pengeringan yang lebih rendah serta pada saat massa Teflon $(\mathrm{m})$ makin banyak, dengan nilai koefisien korelasi (r) berturut-turut sebesar $-0.161,-0.415$ dan 0.667 . Kenaikan secara siginifikan pada nilai b sampel bubuk sari jagung manis selama pengeringan metode SVB terjadi ketika menggunakan butiran Teflon sebanyak $1.3 \mathrm{~kg}$ (Gambar 5). Mengingat rata-rata nilai atribut warna $b$ lebih besar dibandingkan dengan nilai a, maka dapat disimpulkan bahwa sampel bubuk sari jagung manis instan yang dihasilkan dalam percobaan ini lebih menonjolkan kesan warna yellowness (kekuningan) daripada redness (kemerahan).

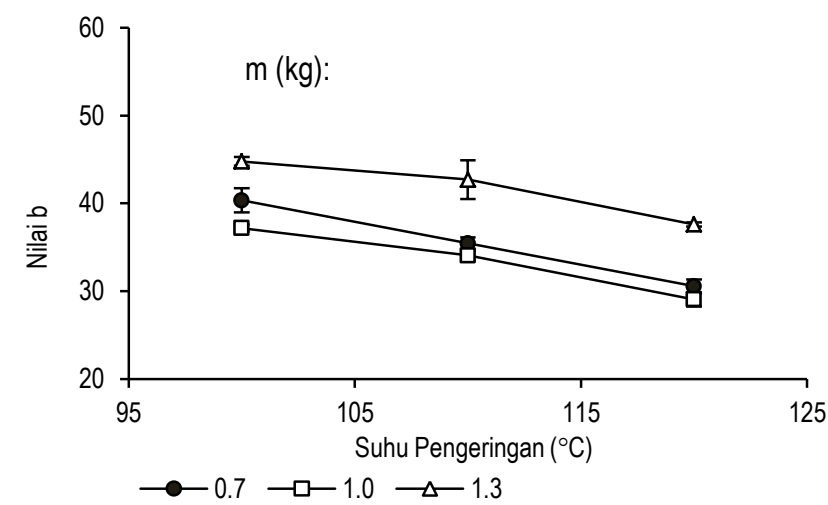

Gambar 5. Hubungan suhu pengeringan dengan nilai $b$ warna bubuk sari jagung manis pada saat $F=1.5 \mathrm{~kg} / \mathrm{jam}$ dan $Q=323$ $\mathrm{m}^{3} / \mathrm{jam}$

\section{Densitas partikel}

Densitas partikel bubuk sari jagung manis instan merupakan sifat fisik yang berhubungan dengan riwayat penanganan dan proses pengolahan bahan tersebut yang berguna dalam perencanaan pengemasan. Seperti ditunjukkan pada Tabel 2 bahwa laju pengumpanan bahan (F) dan masa Teflon (m) mempunyai pengaruh yang signifikan terhadap nilai densitas partikel bubuk instan dengan nilai koefisien korelasi (r) masingmasing 0.412 dan 0.333. Gambar 6 menunjukkan bahwa peningkatan laju pengumpanan bahan selama proses pengeringan menggunakan metode SVB mengakibatkan kenaikan nilai densitas partikel bubuk instan. Selama percobaan ini, peningkatan laju pengumpanan bahan (F) dalam proses pengeringan cenderung menghasilkan bubuk sari jagung manis dengan kadar air yang lebih tinggi. Apabila massa sampel bubuk tersebut menjadi lebih tinggi untuk ukuran jenis partikel yang sama maka hal ini dapat menyebabkan peningkatan densitas partikel bubuk sari jagung manis instan yang dihasilkan dengan kondisi pengeringan tersebut. Kepadatan (compactness) bubuk sari jagung manis dapat ditingkatkan bila ukuran butiran partikelnya dapat diperkecil melalui mekanisme penggilingan oleh gerakan butiran Teflon yang terfluidisasi di dalam ruang pengering. Karena itu, penggunaan massa Teflon yang lebih besar selama pengeringan bahan cair menggunakan metode SVB dapat memperbaiki proses penggilingan produk kering di dalam ruang pengering, sehingga dapat diperoleh bubuk sari jagung manis instan dengan ukuran partikel lebih kecil dan lebih compact, yang tentu saja menjadi lebih besar nilai densitas partikelnya.

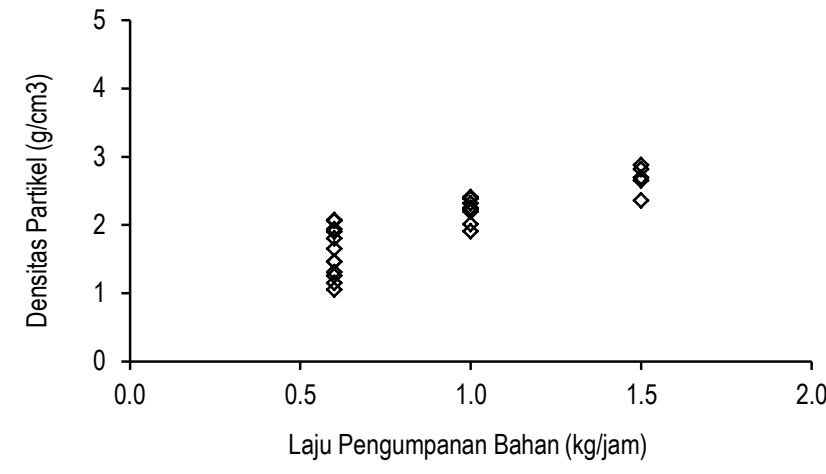

Gambar 6. Hubungan laju pengumpanan bahan dengan densitas partikel produk pada saat $\mathrm{T}=100=120^{\circ} \mathrm{C} ; \mathrm{m}=0.7-1.3 \mathrm{~kg}$ dan $\mathrm{Q}=245-323 \mathrm{~m}^{3} / \mathrm{jam}$

\section{Indeks kelarutan (SI)}

Indeks kelarutan (SI) adalah kemampuan bubuk sari jagung manis instan untuk melarutkan diri dalam air pada saat dimanfaatkan sebagai bahan minuman. Semakin cepat produk itu terlarut dalam air maka semakin praktis proses penyeduhannya dan semakin baik kualitas produk bubuk instan tersebut. Koefisien korelasi (r) antara nilai SI bubuk instan dengan variabel kondisi pengeringan SVB dicantumkan pada Tabel 2. Nilai SI bubuk sari jagung manis instan menurun jika dikeringkan dengan suhu pengeringan $(T)$ yang lebih tinggi $(r=-0.430)$. Hal ini kemungkinan akibat dari terjadinya kenaikan kejenuhan pada larutan yang mungkin disebabkan oleh peningkatan efek denaturasi protein. Meskipun tidak signifikan, peningkatan laju pengumpanan bahan $(F)$ selama proses pengeringan menggunakan unit SVB juga menyebabkan penurunan nilai SI bubuk instan yang dihasilkan dengan nilai koefisien korelasi ( $r$ ) sebesar -0.174 . Penambahan laju hembusan udara pengering (Q) pada saat pengering SVB dijalankan pada suhu $100-110^{\circ} \mathrm{C}$ dan massa Teflon $1.3 \mathrm{~kg}$ mengakibatkan penurunan indeks kelarutan (SI) bubuk sari jagung manis instan seperti ditunjukkan pada Gambar 7.

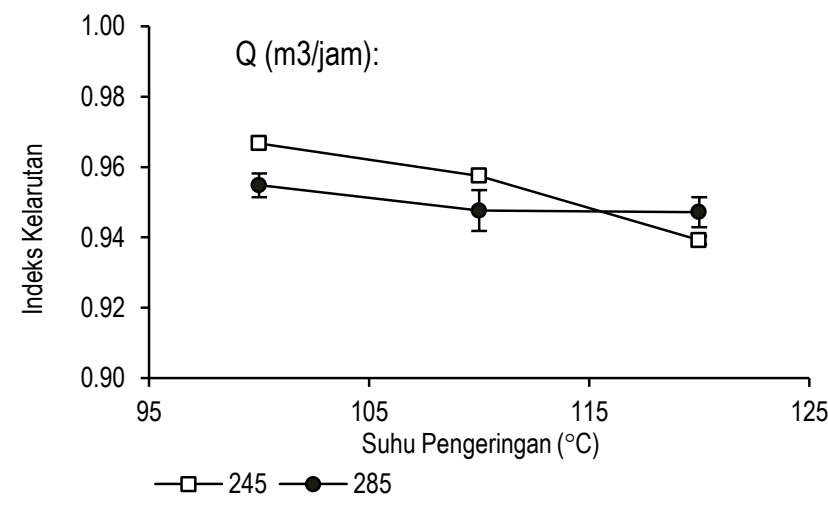

Gambar 7. Hubungan suhu pengeringan dengan indeks kelarutan (SI) bubuk sari jagung manis instan pada saat $F=0.6 \mathrm{~kg} / \mathrm{jam}$ dan $m=1.3 \mathrm{~kg}$

\section{Kapasitas absorpsi air}

Kemampuan bubuk sari jagung manis instan untuk menyerap air merupakan salah satu sifat penting yang harus diketahui jika kita akan memanfaatkan produk ini sebagai bahan 
fortifikasi produk pangan. Nilai kapasitas absorpsi air $\left(\mathrm{W}_{\mathrm{a}}\right)$ bubuk sari jagung manis instan hasil percobaan ini berkisar antara 1.98 dan $5.38 \mathrm{ml} \cdot \mathrm{g}^{-1}$ tergantung pada kondisi pengeringan. Keragaman nilai $W_{a}$ tersebut sangat ditentukan oleh tiga variabel kondisi pengeringan SVB yaitu laju kecepatan udara pengeringan $(Q)$, laju pengumpanan bahan $(F)$ dan jumlah butiran Teflon (m). Tabel 2 menunjukkan bahwa peningkatan nilai $W_{a}$ bubuk instan akan diperoleh jika bahan cair dikeringkan dengan kecepatan udara pengering $(\mathrm{Q})$ yang lebih rendah $(r=-0.479)$. Namun sebaliknya, operasional variabel $F(r=0.411)$ dan variabel $m(r=0.403)$ yang semakin tinggi dalam proses pengeringan larutan sari jagung manis, telah menghasilkan bubuk instan dengan nilai $W_{a}$ yang semakin besar. Gambar 8 menunjukkan bahwa pengaruh variabel $F$ terhadap variasi nilai $W_{a}$ bubuk sari jagung manis instan hanya tampak saat kecepatan udara pengeringan (Q) dioperasikan selain daripada $323 \mathrm{~m}^{3} / \mathrm{jam}$. Daya serap air suatu bahan umumnya tergantung pada sifat fisikokimia dan komposisi dari bahan tersebut, yang akan mengalami perubahan baik diinginkan maupun tidak selama proses pengolahan seperti pengeringan.

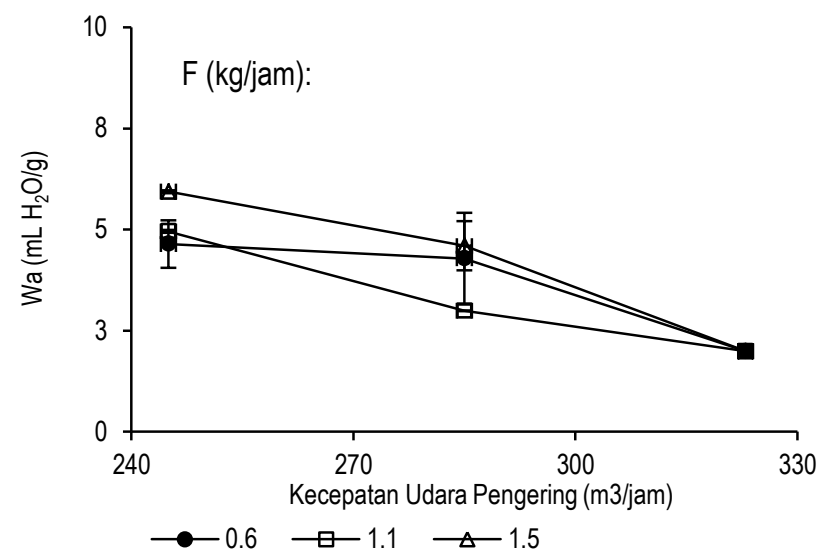

Gambar 8. Hubungan kecepatan udara pengering $(\mathrm{Q})$ dengan nilai $\mathrm{W}_{\mathrm{a}}$ bubuk sari jagung manis instan pada saat $\mathrm{T}=100^{\circ} \mathrm{C}$ dan $\mathrm{m}$ $=1.3 \mathrm{~kg}$

\section{KESIMPULAN}

Eksperimen pengeringan sari jagung manis menggunakan metode SVB telah menghasilkan bubuk instan dengan karakteristik kadar air, densitas partikel, indeks kelarutan dan kapasitas penyerapan air sebesar $3.0-11.4 \%$ bb, 1.05-2.98 g.cm-3, $0.87-0.97$ dan 1.98-5.38 mL.g-1 tergantung pada kondisi suhu pengeringan, laju pengumpanan bahan, laju udara pengeringan dan massa partikel inert. Tingkat kecerahan (lightness) warna bubuk sari jagung manis instan bernilai mulai 48.7 hingga 66.9 , dan sangat dipengaruhi secara nyata oleh mayoritas variabel kondisi pengeringan SVB yang digunakan dalam percobaan ini. Massa partikel inert (Teflon) dan suhu pengeringan merupakan variabel paling dominan yang secara nyata mempengaruhi karakteristik bubuk sari jagung manis instan.

\section{UCAPAN TERIMA KASIH}

Penulis menyampaikan penghargaan dan ucapan terima kasih kepada Lembaga Penelitian Universitas Jember yang telah membantu dan mendukung keberhasilan riset ini melalui program hibah Insentif Penguatan Penelitian Unggulan (IPPU).

\section{DAFTAR PUSTAKA}

[AOAC] Association Official Analytical Chemist. 1999. Official Method of Analysis. Association of Official Analytical Chemist. Washington DC.

Ghorpade VM, Hanna MA, Jadhav SJ. 1998. Sweet Corn. In Handbook of Vegetable Science and Technology, edited by D.K. Salunkhe and S.S. Kadam. New York, Marcel Dekker Inc. 609-646.

Iskandar D. 2003. Pengaruh Dosis Pupuk N, P dan K Terhadap Pertumbuhan dan Produksi Tanaman Jagung Manis di Lahan Kering. Prosiding Seminar Teknologi untuk Negeri $p$. 1-5. HUMAS-BPPT/ANY.

Kudra T, Mujumdar AS. 2009. Advanced Drying Technologies, Second Edition. 29-54. CRC Press, Boca Raton, FL.

Lees R. 1971. Laboratory Handbook of Methods of Food Analysis. Leonard Hill, London, UK.

Lertrat K, Pulam T. 2007. Breeding for increased sweetness in sweet corn. Int J Plant Breeding 1: 27-30.

Liu-juan Y, Cui-ji H, You-fen T, Jun-sheng L. 2011. Influence of sweet corn juice on the fermentation and storage characteristics of sour extract. J Anhui Agric Sci 13: 77237725.

Manurung H. 2011. Diversifikasi pangan Bebasis Tepung: Meningkatkan Kesehatan Masyarakat dan Ketahanan Pangan. Prosiding Seminar Nasional Perhimpunan Ahli Teknologi Pangan Indonesia (PATPI) Sumatera Utara p. 311-317: USU Press, Medan.

Mohsenin NN. 1980. Physical Properties of Plant and Animal Materials: Structure, Physical Characteristics and Mechanical Properties. Gordon and Breach Sci. Publisher, New York.

Nofrianti R, Azima F, Eliyasmi R. 2013. Pengaruh penambahan madu terhadap mutu yogurt jagung. J Aplikasi Teknol Pangan 2: 60-67.

Prabhavat S, Kanchanapakornchai U, Boonyaratanakornkit M, Tiengpook C, Boonvisut S, Poosimuang S. 1999. Canned corn beverage from sweet corn kernel and its cob. Kasetsart J Nat Sci 33: 430-443.

Sangsila A, Thaochalee M, Ali N, Itsaranuwat P. 2012. Development of probiotic yoghurt-like products from corn extract. Khon Kaen Agr J 40: 218-223.

Setiawati BB, Puspitojati E. 2011. Evaluasi mutu yogurt formulasi susu jagung manis-kedelai. J IImu-IImu Pertanian 1: $14-23$.

Setyani S, Medikasari, Astuti WI. 2009. Fortifikasi jagung manis dan kacang hijau terhadap sifat fisik, kimia dan organoleptik 
susu jagung manis kacang hijau. J Teknol Industri dan Hasil Pertanian 2: 107-119.

Srianta I, Kuswardani I, Tanur AE, Anita F, Lini V. 2010. Development of low aflatoxin soycorn extract: optimisation of soybean and sweet corn ratio and its stability during storage. Int J Food Nutr Public Health 2: 161-170.

Supavititpatana P, Wirjantoro TI, Raviyan P. 2009. Effect of sodium caseinate and whey protein isolate fortification on the physical properties and microstructure of corn extract yogurt. CMU J Nat Sci 8: 247-263. DOI: 10.12982/ CMUJNS.

Sutardi, Hadiwiyoto S, Murti CRN. 2010. Pengaruh dekstrin dan gum arab terhadap sifat kimia dan fisik bubuk sari jagung manis. J Teknol dan Industri Pangan 21: 102-107.

Taruna I, Kurniawan Y, Hendratno ET, Setyagung A. 2005 Drying of coconut extract in a spouted-vortex-bed of inert particles. Proceeding of the ITSF Seminar on Science and
Technology (Session B), Shangri-La Hotel, Jakarta, Indonesia, 2 ${ }^{\text {nd }}$ February 2005.

Traina MS, Breene WM. 1994. Composition, functionality and some chemical and physical properties of eight commercial full-fat soy flour. J Food Process Pres 8: 229-252. DOI: 10.1111/j.1745-4549.1994.tb00846.x.

Trisnawati CY, Srianta I, Marsono Y. 2013. Effect of corn varieties on the characteristics of soycorn extract. Int Food Res J 20: 1187-1190

Welirang F. 2002. Tepung Jagung Alternatif Pangan yang Pas. Laporan Khusus Trubus: 390 p, 73-74.

Wen-ming D, Wei Y, Wei W, Jin-liang S, Da-hai G. 2004. The processing technology of sweet corn beverage. Food and Machinery 20: 41-42.

Xing-wu T. 2006. Application study of a-amylase in the production of sweet corn beverage. J Hubei Univ Technol 2: 17-20. 